\title{
The Coloniser and the Colonised: Reflections on Translation as Contested Space
}

\author{
Harry Aveling
}

\begin{abstract}
ABSTRAK Tulisan inimengemukakan pentingnya pemahaman penerjemah mengenai "kata" dari sebuah karya. Kata "coloniser" dan "colonised" yang muncul dalam karya Albert Memmi memiliki relevansi dengan pengertian kolonial yang bersifat metaforis. Oleh karena itu, seorang penerjemah, dalam melihat kedua kata itu, haruslah terfokus pada teks itu sendiri dan merefleksikannya. Secara singkat ada banyak cara untuk melihat karakteristik yang beragam dari hubungan antara penerjemah beserta terjemahannya dan penulisnya

KATA KUNCI coloniser, colonised, colonial metaphor, translator, translated
\end{abstract}

In her "critical introduction" to postcolonial theory, Leela Gandhi speaks the "new fields of knowledge - often classified under the rubric of the 'new humanities' - [which] have endeavoured first, to foreground the exclusions and elisions which confirm the privileges and authority of canonical knowledge systems, and second to recover those marginalised knowledges which have been occluded and silenced by the entrenched humanist curriculum "(Gandhi 1998: 42). These fields are, in the words of Michel Foucault, "subjugated knowledges ... knowledges that have been disqualified as inadequate to their task or insufficiently elaborated: naïve knowledges, located low down on the hierarchy, beneath the required level of cognition or scientificity (Foucault 1980: 82); Gandhi 1998: 43)." From among these knowledges, Foucault cites "that of the psychiatric patient, of the ill person, of the nurse, of the doctor ... of the delinquent, etc" (Foucault 1980: 82). Gandhi's examples are perhaps these days more respectable: "disciplines such as women's studies, cultural studies and gay/lesbian studies" - and postcolonial studies, of course (Gandhi 1998: 42). Translation Studies is one of "the new humanities"1 and sits somewhere between the types of knowledge which Foucault and Gandhi describe.

In this paper, I come as both a practitioner and a scholar of translation. I

$1 \quad$ Susan Bassnet's book Translation Studies, Methuen, London 1980, p. 1, credits the name of the new discipline to a proposal made by André Lefevere in 1976: her book is "an attempt to demonstrate that Translation Studies is inded a discipline in its own right; not merely a minor branch of comparative literary study, nor yet a specific branch of linguistics, but a vastly complex field with many far-reaching ramifications." 
have translated extensively from Indonesian and Malay, co-translated from Hindi, and have done some preliminary work on Francophone Vietnamese writing. Here, I am interested in using Albert Memmi's book, The Colonizer and the Colonized, as providing a metaphor which might be useful for thinking about the act of translation and its problems.

\section{Albert Memmi}

Albert Memmi was born in Tunisia in 1920, a Jew in a predominantly Muslim French colony. His father was a saddler. Memmi's maternal language was Arabic. He was educated firstly in a rabbinical school, then at the Alliance israélite, and finally at a French high school in Tunisia. His studies at the University of Algiers were interrupted by the Second World War, when he was interned in a forced-labour camp in 1943, but he later proceeded to the Sorbonne, receiving his agrégation in philosophy. Returning to Tunisia, with a French wife, he began work in the field of child psychology and campaigned actively for Tunisian independence as editor of the literary page of the Tunisian daily L'Action. After Tunisia acquired its independence in September 1956, he settled permanently in Paris, where he subsequently divided his time between academic work and writing.

Memmi has written five novels, La Statue de sel (1953), Agar (1955), Le Scorpion (1969), Le Désert (1977), and Le Pharoan (1989), as well as a collection of poetry, Le Mirliton du Ciel (1990). His most influential work is the essay Portrait du Colonisé précédé du Portrait du Colonisateur (A Portrait of the Colonized, preceded by a Portrait of The Coloniser), first published in 1957 and translated into English by Howard Greenfield in 1965. Memmi has also published other studies,including Portrait d'un Juif (1962), La Libération du Juif (1966), L'Homme Dominé (1968), La Dépendance (1979) and Le Racisme (1982). He is the subject of two volumes of interviews, Entretien (1975) and La Terre intérieure (1976); and has also edited two anthologies of North African Francophone writing: L'Anthologie des écrivains maghrébins d'expression française (1964) and L'Anthologie des écrivains française du Maghreb (1969) (Monego 1984: 91 -93); Déjeux 1973: 303-304).

In describing his own life in La Terre intérieure, Memmi says: "This will be, in sum, the history of a certain type of provincial Frenchman, who earned the necessary capital with which he was able to lead an acceptable life. There is nothing more to add but the date of my death ...". But, in fact, he continues: "it is not that simple; there was also colonisation, the war, decolonisation ... Let me say things differently: I was the first son in a family which had eight children; my father, a saddle-maker, had some difficulty in earning enough to procure what we needed. We were thoroughly Jewish in an Arabic country which, even if the land was a French protectorate, still created many difficulties. Finally, we were Tunisians, both colonised and belonging to the second zone of France. I always wanted to write, I'm sure of that. Always, through every difficulty, the experience of being humiliated, the daily witnessing of injustice, the atrocious brutality of modern warfare, the 
German occupation, the extraordinary historical surprise of decolonisation, my journeys throughout the world, where I was exposed to other situations, discovered other itineraries similar to my own, has all made me a polemical writer (un écrivain de combat). Finally, in that regard, I have said almost all that I would like to say: I would like to return permanently to writing fiction, to the novel. Let us add, for the sake of completeness, that I would have liked to have been a physician or a priest ... But I was required to study to become a professor; very well, I have learned to love this trade, I feel comfortable in it, and I can write a little almost every day ..." (Memmi 1985: 216 - 217).

\section{The COLONIZER AND THE COLONIZED}

As a writer, Memmi has been associated with the "Generation of 1952", described by Joan Monego as "the first generation of accomplished Maghrebian writers (Memmi 1984: 21); (Ibnlfassi 1996: 11-30)." Memmi says of these writers in his introduction to L'Anthologie des écrivains maghrébins d'expression française: "For the first time, North Africa can be seen to take itself on. Accepted, assumed, or discussed, she ceases to be a simple décor or a geographic accident. These new authors are at grips with their country as with the essential of themselves ... It was necessary to dare at last to grasp at one's own life, at that of one's fellow citizens, at the relations with the colonizer. It was necessary, in sum, to discover and affront one's veritable domain, one's specific object. And that isn't to be taken for granted when one has lost the habit of disposing of one's own destiny"(Memmi 1984: 20 - 21).

In the 1965 Preface to The Coloniser and the Colonised, Memmi similarly suggests that: "I undertook this inventory of conditions of colonized people mainly in order to understand myself and to identify my place in the society of other men" (p. 4). His conclusions are given briefly in this opening preface and worth summarising here. At the heart of the colonial relationship is the economic privilege of the coloniser. The deprivations of the colonized - his daily humiliation and objective subjugation - are the almost direct result of the colonizer's advantages (p. 8). The relationship is, thus, one of "implacable dependence", which has "molded their respective characters and dictated their conduct". Nevertheless: "Just as there was an obvious logic in the reciprocal behavior of the two colonial partners, another mechanism, proceeding from the first, would lead, I believed, inexorably to the decomposition of this dependence" (p.5). Memmi concludes: "It was probably sufficient to describe with precision the facts of colonization, the manner in which the colonizer was bound to act, the slow and inevitable destruction of the colonized, to bring to light the absolute iniquity of colonization; and at the same time, to unveil the fundamental instability of it and predict its demise" (p. 13).

As a postwar commentator on French colonialism, Memmi's work is contemporary with that of Franz Fanon, a physician from Martinique, and (Dominique) O. Mannoni, an Italian psychologist practising in Madagascar. He has a similar interest to them in the emotional consequences of oppression, and especially the factor of dependence. Here I wish simply to describe the rest of 
Memmi's book in brief detail, before I look for the possible parallels between the colonized and the colonized, and the translator and the translated.

\section{THE COLONIST}

Part One of The Coloniser and the Colonised presents a "Portrait of the Colonizer". Memmi opens with a paragraph drawn straight from the French equivalent of the Boys Own Paper: "We sometimes enjoy picturing the colonizer as a tall man, bronzed by the sun, wearing Wellington boots, proudly leaning on a shovel - as he rivets his gaze far away on the horizon of his land. When not engaged in battles against nature, we think of him laboring selflessly for mankind, attending the sick, and spreading culture to the nonliterate. In other words, his pose is one of a noble adventurer, a righteous pioneer" (p. 47).

Such a picture of "the cultural and moral mission" of the colonist "is no longer tenable" - if it ever was (p. 47). The colonist's major motive is economic: "a colony [is] a place where one earns more and spends less" (p. 48). His position (Memmi uses the masculine pronoun throughout) has a "double illegitimacy": "he has succeeded not merely in creating a place for himself but also in taking away that of the inhabitant, granting himself astounding privileges to the detriment of those rightfully entitled to them" (p. 53).

Memmi's next chapters deal respectively with "The colonizer who refuses" and "The colonizer who accepts". The colonizer who refuses is "astonished by the large number of beggars, the children wandering about half-naked, trachoma, etc., ill at ease before such obvious organization of injustice, revolted by the cynicism of his fellow citizens" (p. 63). If he does not immediately return home, "he lives his life under the sign of a contradiction which looms at every step, depriving him of all coherence and tranquillity" (p. 64). Renouncing a part of himself, he will also discovers that: "if the colonized have justice on their side, if he can go so far as to give them his approval and even his assistance, his solidarity stops here; he is not one of them and has no desire to be one" (p. 67).

Having set aside "both the problem of his own privileges and that of his emotional difficulties, only his ideological and political attitudes remain to be considered" (p.71, punctuation modified). Memmi suggests that the dissident colonist's attitudes (" political democracy and freedom, economic democracy and justice, rejection of racist xenophobia and universality, material and spiritual progress", p. 78) are not always important to those with whom he seeks to identify himself. They, perhaps, "aspire to be religious", or "show no concern for individual freedom" (p. 76). Ultimately, they do not "love" him (p. 81); they "are "not his people and never will be" (p. 83), and "he will go on being what he is, with his language intact and his cultural traditions dominating" (p. 84). Eventually, everything will confirm "his solitude, bewilderment and ineffectiveness" (p. 87) before he is finally reduced to silence (p. 88).

"The colonizer who accepts" confirms and affirms the colonial relationship. He is, no doubt, "mediocre" enough to persist (p. 92); conservative in his 
politics; able to "approve discrimination and the codification of injustice" (p. 99); and faithful to the memory of his homeland (p. 105), to which, however, he also feels superior (pp. 108-9). Racism is "the consubstantial part" of colonialism (p. 118). It requires: "one, the gulf between the culture of the colonialist and the colonized; two, the exploitation of these differences for the benefit of the colonialist; three, the use of these supposed differences as standards of absolute fact" (p. 115). The "final act of distortion" is that: "Custodian of the values of civilization and history, he accomplishes a mission; he has the immense merit of bringing light to the colonized's ignominious darkness. The fact that his role brings him privileges and respect is only justice; colonization is legitimate in every sense and with all its consequences" - there will be no end to his domination. In this "new moral order", "he has no duties and the colonized have no rights" (p. 120).

\section{THE COLONIZED}

Part Two of The Coloniser and the Colonised also begins with an image, a "Mythical portrait of the colonized". The colonized is, of course, "lazy" (p. 123) and "a weakling" (p. 125), and so on - all these are "negations" which are considered to be the result of psychological or ethical inadequacy (p. 128). The colonized is further depersonalized by "the mark of the plural" - the indiscriminate use of the pronoun "they" ("They are all this." "They are all the same", p. 129). Finally, the colonized is not free, and certainly "not free to choose between being colonized or not being colonized" (p. 130). In these ways, the colonized becomes an object, existing only as "a function of the needs of the colonizer" (p. 130).

These definitions confine the colonized to acting in what Memmi next describes as "situations of inadequacy". These situations are characterized by the destruction of the colonized's sense of history (p. 136) and the "mummification of the colonized society" (p.142); by the lack of contemporary power and community (p. 139); as well as by the loss of a living language (p. 150) and a living literature (p. 152).

The colonized has "two answers" to his oppression. The first is assimilation, which can only "meet with disdain from the colonial masters" (168), because its only outcome would be the end of the colonial relationship - which the colonialist would never allow (pp. 170-1). The other is revolt, beginning with the creation of a "counter-mythology" in which everything in his own culture "is good, everything must be retained among his customs and traditions, his actions and plans; even the anachronous or disorderly, the immoral or mistaken. Everything is justified because everything can be explained" (p. 183).

In The Wretched of the Earth, Fanon insists that "decolonization is always a violent process (Fannon 1969: 27; Alessandrini 1999: 235-237). Memmi's sense of what comes after colonization is more moderate, perhaps more existentialist. In his Conclusion, he suggests, firstly, that: "Having abandoned the colonial framework, it is important for all of us to discover a new way 
of living with that relationship. I am one of those who believe that to find a new order of things with Europe means putting a new order in oneself" (pp. 190-1). Memmi does say that "To live, the colonized needs to do away with colonization." But, more subtly, he immediately continues: "To become a man, he must do away with the colonized being he has become" (p. 195). To become "a whole and free man" (p. 197), enjoying "complete liberation" (p. 195), "he must conquer himself and be free in relation to [the] nation ... [and] the religion of the group" (p. 196). Then at last he will become "a man like any other" (p. 197).

\section{THE TR ANSLATOR AND THE TRANSLATED}

These myths of power, the dominance of the colonialist and the dependence of the colonized potentially have their parallels, and contradictions, in the small scale field of translation. Much of what I will say comes out of my own experience, and my own examples will be largely drawn from Indonesian and Malay writing in English.

\section{TRANSLATION AND POWER}

Let us begin our study of the colonization metaphor with a heroic myth of translation, taken in this case from the web-site of the American Literary Translators Association: "Translation Studies is a formal branch of academic study that addresses critical, creative, and research issues involved in the linguistic and interpretive transferral of sense and sound from one language to another and from one cultural context to another. Translation Studies explores all dimensions of the translation process ... [Translation] is an exacting art that demands creative expression, philological precision, minute knowledge of historical and cultural contexts, and a nuanced sense of style in both the source and target languages."

Sometimes yes, and sometimes no, it must be admitted. Translations are done for all sorts of reasons, for all sorts of audiences, and within all sorts of constraints. And translations are not simply disinterested "intellectual and creative activity". Even if the rewards are not great, perhaps the majority of translators work full time as a way of earning a living. Others (ALTA members and their colleagues, perhaps) turn their professional skills into other forms of capital - exactly in the shape of "promotion and tenure". While a few even translate purely for their own personal satisfaction. Those who are most dependent on translation for their living are, of course, the most caught up in the patterns of national and international literary trade. They are the ones who are most conscious of the importance of the dominant norms in their own literary systems and the need to adopt specific norms, behaviours and policies. Scholar-translators too must also take account of the principles of prestige and dominance which characterise their own educational systems - and the relationship of those systems to international education. They are, in a sense, both colonizer of the foreign literature and colonized by the demands to conform to their own cultures if they are to be successful. 
Another way of understanding this colonizing is to recognize that translations inevitably involve an ideological element. As Susan Bassnett and Andre Lefevere state in their Introduction to Edwin Gentzler's Contemporary Translation Theory,: "All rewritings, whatever their intention, reflect a certain ideology and a poetics and as such manipulate literature to function in a given society in a given way. Rewriting is manipulation, undertaken in the service of power, and in its positive aspect can help in the evolution of a literature and a society. Rewritings can introduce new concepts, new genres, new devices, and the history of translation is also the history of literary innovation, of the shaping power of one culture on another. But rewriting can also repress innovation, distort and contain, and in an age of ever increasing manipulation of all kinds, the study of the manipulative processes of literature as exemplified by translation can help us towards a greater awareness of the world in which we live" (Bassnett 1999: ix).

The play of manipulation in the service of power in bridging the differences between the differing factors of both the source and target literary polysystems (these factors include different producers, consumers, institutions, repertoires, market and product) inevitably holds even between literatures that are relatively close. (And despite American poet Wallace Stevens' optimistic pronouncement - "French and English constitute a single language" (Auster 1984: xxvii) - we know that this is not really so. Those who doubt this should begin with the first sentence of Marguerite Duras's "Ecrire": "C'est dans une maison qu'on est seul."2) When the relationship between the two systems is based on distinct inequalities, as in colonial or global market relations, the differences can be much stronger and much more obvious. Douglas Robinson provides a convenient summary of Richard Jacquemond's four hypotheses on "the problems of translating across power differentials":

1. A dominated culture will invariably translate far more of the hegemonic culture than the latter will of the former.

2. When the hegemonic culture does translate works produced by the dominated culture, those works will be perceived and presented as difficult, mysterious, inscrutable, esoteric and in need of a small cadre of intellectuals to interpret them, while a dominated culture will translate a hegemonic culture's works accessibly for the masses.

3. A hegemonic culture will only translate those works by authors in a dominated culture that fit the former's preconceived notions of the latter.

4. Authors in a dominated culture who dream of reaching a large audience will tend to write for translation into a hegemonic language, and this will require some degree of compliance with stereotypes (Robinson 1997: $31-32)$.

To be a translator from a dominant culture is thus to be part on an ongoing process of colonization. However, this discussion of power too needs to be

2 see Ecrire, Gallimard, Paris 1993, p. 15. On the cross-cultural nature of Duras's own work, see Catherine Bouthors-Paillart: Duras la métisse: Métissage fantasmatique et linguistique dans l'oeuvre de Marguerite Duras, Droz, Geneva 2002. 
further nuanced, because it suggests that there is only one center of power, that to be found in Europe. In the same lectures we referred to earlier in this paper, Foucault has argued: "Power must be analysed as something which circulates, or rather as something which only functions in the form of a chain. It is never localised here or there, never in anybody's hands, never appropriated as a commodity or a piece of wealth. Power is employed through a net-like organisation" (Foucault 1980: 98). Within the literary system of English, there are, in fact, multiple centers and multiple dominations - it is not the same thing to publish a translation in Brisbane, Australia, as it is to publish in Athens, Ohio; and not the same thing to publish in Athens, Ohio as it is to publish in New York City, New York. Within the so called "dominated culture" - in Hong Kong, Singapore, Kuala Lumpur and New Delhi, publishers may also want to publish English translations, for various reasons - including prestige, sentiment, the desire to publicise national cultures, and the hope of wider markets. Here other chains of power come into play: dominated cultures may be hegemonic cultures in their own territories.

\section{THE TRANSLATOR}

The "translator who accepts" the norms, behaviors and policies of the dominant literary system will produce works that are congruent with the expectations of the home market. In the case of translation from Indonesia, the most commercially successful translations have confirmed the impression that Indonesia is governed by a heavily authoritarian military regime, which has a brutal disregard for human rights. The Indonesian writers translated have been promoted in the West as brave individuals committed to democracy and personal freedom. Pramoedya Ananta Toer, imprisoned by the Suharto regime for almost two decades, fits this mould exactly, as did Mochtar Lubis (on the right) before him, under Sukarno. The translator who accepts confirms that there are differences between "us" and "them" of a moral and political nature, in which we are superior.

The "translator who refuses" can move in two different directions. One direction is to attempt to introduce the translated literature into the home literary system on its own terms, as a literary sub-system perhaps, that of the translated text, but still as one that has an interest in its own right. (Books which are too much "like our own" will need to be extraordinarily good to make any impression at all.) This interest will normally consist in the variations of the source literary norms from, and their challenges to, the target literary system. An Indonesian woman writer may stand as an example of new styles of feminism, saying things that women writers elsewhere have not yet said. An example is Dorothea Rosa Herliany, whose poem entitled "Wedding Diary" begins: "When I married you, I never promised to be faithful/ in fact you agreed to be my slave ..." (Herliany 2004: 166). A dramatist, such as Arifin C. Noer, can show different ways of moving theatrical action between the world of the real and that of the dream, through the use of wayang shadow 
play techniques. ${ }^{3}$ A surrealist short story writer, such as Danarto, can open the world of narrative to mystical pantheistic influences that are important in Javanese culture but less obvious in most contemporary English literature. ${ }^{4}$ Or so one hopes anyway.

Another direction is to translate and publish in the dominated region itself. Here the translator's case is similar to that of the liberal colonist. In translating books that are central to the literary norms of the dominated system, it may well be found that methods of characterisation, plot development, and moral assessment are not those with which one is necessarily comfortable. Commissioned translations are often of works that are important in the source culture but likely to be of lesser interest to the assumed target audience.

In my youth, I decided to translate the great Malay novel Salina - great most especially because it is almost five hundred pages long - but once started, I also felt that it was unnecessarily repetitive and unlikely to sustain the interest of readers used to a more concise style. Consequently, my final translation was about half the size of the original, and appared even shorter when it was published in a small book format on thin paper (Said 1961: 495); Said 1975: 278). Today graduate students in Malaysia write doctoral theses on my shortcomings. What I didn't realise at the time was that my translation would only be read in the region itself: the local norms applied to both the English and the Malay texts. (I have also had the opposite honor of being told by a young Philippine scholar: "You are our gateway to Indonesian literature". As none of my translations have been published in the Philippines, the student had presumably relied on photocopies of those books which were published in Singapore and Hong Kong - by Heinemann Educational Books (Asia) Pty Ltd.)

Both the translator who accepts and the one who refuses are, in their different ways, colonized by the text - its words, grammatical problems, rhythm, tone and its linguistic, social and cultural meanings (Bly 1983). They may be colonized by the assumption of inferiority that translators often labor under, and the sense that what "they" translate is not as important as what "we" write. There is another form of potential colonization of the translator as well - by the colonized. Translators are often sought out by authors who recognise, more clearly than the translator does, that translation into English gives the local author access to a vast literary circuit of publishers, conferences and grants. As a translator who tries to refuse, in this case to refuse to translate work which I do not think is of high standard within its own literary system, or is not likely to be appreciated by English readers (and these two things are not necessarily identical), I have also been abused in public forums by those whom I have slighted in some way or another. The translator can be criticised in considerable linguistic detail by those for whom English is not a first language. One can also be soundly abused by those one has not translated at all. It is hard not to feel, sometimes, that translation is a lose-lose game. As Howard Goldblatt asked in the Washington Post in April 2002: "Who are these see Dewan Bahasa dan Pustaka, Kuala Lumpur on Moths (1975).

see a mystical pantheisteic influences in Javanese culture on Abracadabra, (Danarto 2001). 
people everyone loves to hate, and, if they're so bad, how do they get away with what they're doing?" 5 They are the colonized, translators.

\section{THE TRANSLATED WRITER}

The translated writer (or the writer who hopes to be translated) can agree to translation gracefully, actively seek out a translator, produce work which is "appropriate" for translation, accept invitations to be translated when they come, ignore them when they do not, or consciously refuse them. Most writers, no doubt, do not see translation as the ultimate validation of their work or acceptance by a "dominant" culture as superior to publication in their own. Despite the belief of postcolonial theorists that the center (England) is superior, and the standard by which everything in the Empire measures itself, this is not widely accepted in those "peripheries" which, in fact, commonly regard themselves as the "center" of all that matters - in literature as in everything else. Here the Empire does not "write back"; as I have suggested elsewhere, it simply writes to itself. ${ }^{6}$ At this point, silence is possible - but not inevitable. Relationships between translators and translated authors are many and complex. Foucault, again, reminds us that: "there are no relations of power without resistances; that the latter are all the more real and effective because they are formed right at the point where relations of power are exercised; resistance to power does not have to come from elsewhere to be real, nor is it inexorably frustrated through being the compatriot of power. It exists all the more by being in the same place as power; hence, like power, resistance is multiple and can be integrated in global strategies" (Foucault 1980: 142).

\section{THe SPACE IN-BETWEen}

Margaret Anman has suggested that: "we can talk of 'translation' when a source text (of oral or written nature) has, for a particular purpose, been used as the model for the production of a text in the target culture" (Hatim 2001: 27). Memmi provides us with one metaphor of potential relations based on domination and subordination between the translator and the translated text and author, which I have tried to suggest is worth exploring. There are, indeed, many other ways of imagining this coming together of writer and text, source and target language, foreign and domestic literature and culture, one market-place and another. The relationship has also been seen, positively, as an act of love, a mutually faithful marriage, a creative partnership, a temporary flirtation, or, negatively, as an act of betrayal, violent possession, rape, even murder and cannibalism. ${ }^{7}$ The metaphor one prefers may in the end depend

\footnotetext{
5 see "The Writing Life", Washington Post, Sunday April 28, 2002, Book World, p. 10. I have discussed Goldblatt's remarks in my paper, "Mistakes" in Translation: A Functionalist Approach, presented to the Third Workshop on "The Art of Translation", SOAS, University of London, September 2002; subsequently published in CELT: A Journal of Culture, English Language Teaching \& Literature, 3:1, July 2003, pp. 1-12.

${ }_{6}$ see "Non-English Postcolonial Fictions? The Malaysian Case", SPAN, 36:II, October 1993, p. 405.

see in The Translator's Invisibility, Venuti speaks of "the violence that resides in the very
} 
on the needs of the moment and the personalities of those involved.

Another way of conceptualising the meeting is to see translation as the creation of a "meta-literature", of developing a third space between the original text and the translated text, potentially separate from both. The term, "meta-literature" stems from the essay "Poem and Meta-poem: Poetry from Dutch to English" by the late James Holmes. ${ }^{8}$ Holmes returns us to what I have described above as the heroic myth of translation when he insists that the "meta-poet" must have "acumen as a critic, craftsmanship as a poet, and skill in the analysing and resolving of a confrontation of norms and conventions across linguistic and cultural barriers. Like the critic, the meta-poet will strive to comprehend as thoroughly as possible the many features of the original poem, against the setting of the poet's other writings, the literary traditions of the source culture, and the expressive means of the source language. Like the poet, he will strive to exploit his own creative powers, the literary traditions of the target culture, and the expressive means of the target language in order to produce a verbal object that to all purposes is nothing more nor less than a poem. He differs ... from the critic in what he does with the results of his critical analysis, and from the poet in where he derives the materials for his verse. Holmes argues that "meta-literature" makes use of language to communicate something about literature itself. "Meta-poems" are different kinds of objects from the poem from which they derive. Meta-poems make a comment about the original poem, they clarify what it is doing, what it is about, paraphrase, shift emphases, and even distort its meanings. They interpret "by enactment." What Holmes does not talk about is the differential of power, which transverses the meeting, even in a so-called neutral space. This dimension, it should now be clear, must be of concern to all translators. The third space is not necessarily neutral territory.

And this brings me back to Memmi for the last time. In translation too, "it is important for all of us to discover a new way of living with that relationship" (p. 190). The translator must find a personally satisfying way of participating, consciously, honestly and openly, as one member of "two psychical and cultural realms", in which "the two worlds symbolized and conveyed by the two tongues" are, and are not, in conflict (p. 151). The translator, in this postcolonial world, "must conquer himself [or herself] and be free" (p. 196), an authentic human being in equal relationship with another free human being.

purpose and activity of translation" (p. 18). Rosemarie Waldrop's essay: "Silence, the Devil and Jabès", in (ed.) R. Warren: The Art of Translation, Northeastern University Press, Boston 1989, describes "the pleasure of destruction" involved in breaking apart "this seemingly natural fusion of elements." She insists: "We must wrench apart. We must kill" (p. 226). The energy so released is, in the best Dionysian manner, creative energy.

8 see and check on The essay is included in Holmes: Translated Papers in Literary Translation and Translation Studies, Rodopi, Amsterdam 1988. 


\section{LIST OF REFERENCE}

Alessandrini, Anthony (ed.) (1999), Frantz Fanon: Critical Perspectives, London: Routledge.

Ashcroft, Bill, Gareth Griffiths and Helen Tiffin (1989), The Empire Writes Back: Theory and Practice in Post-Colonial Literatures, London: Routledge.

Auster, Paul (ed.) (1984), The Random House Book of Twentieth Century French Poetry, New York: Vintage Books.

Aveling, Harry (2003), "'Mistakes' in Translation: A Functionalist Approach", CELT: A Journal of Culture, English Language Teaching \& Literature, 3:1, July, pp. 1-12.

Aveling, Harry (1993), "Non-English Postcolonial Fictions? The Malaysian Case”, SPAN, Special Issue 36, Vol. II, October, pp 394-405.

Bassnett, Susan and Harish Trivedi (eds.) (1999), Post-Colonial Translation, London: Routledge.

Bassnett-McGuire, Susan (1980), Translation Studies, London: Methuen.

Bhabha, Homi (1994), The Location of Culture, London: Routledge.

Bouthors-Paillart, Catherine (2002), Duras la métisse: Métissage fantasmatique et linguistique dans l'oeuvre de Marguerite Duras, Geneva: Droz.

Bly, Robert (1983), The Eight Stages of Translation, Boston: Rowan Tree Press.

Déjeux, Jean (1973), Littérature Maghrébine de Language Française, Ottawa: Naaman.

Donaldson, Laura (1992), Decolonizing Feminisms: Race, Gender and Empire-Building, London: Routledge.

Duras, Marguerite (1993), Ecrire, Paris: Gallimard.

Fanon, Frantz (1970), Black Skin, White Masks, trans. C.M. Markmann, London: Paladin .

Fanon, Frantz (1969), The Wretched of the Earth, trans. C. Farrington, Harmondsworth: Penguin.

Foucault, Michel (1980), Power/Knowledge: Selected Interviews and Other Writings 1972-1977, ed. C. Gordon, New York: Pantheon.

Foulcher, Keith and A. Day (eds) (2002), Clearing a Space: Postcolonial Readings of Modern Indonesian Literature, Leiden: KITLV.

Gandhi, Leela (1998), Postcolonial Theory, Sydney: Allen \& Unwin.

Herliany, Dorothea Rosa (2004), Life Sentences: Selected Poems, trans. H. Aveling, Magelang: IndonesiaTera

Holmes, James (1988), Translated! Papers in Literary Translation and Translation Studies, Amsterdam: Rodopi.

Iblfassi, Laïla and N. Hitchcott (eds.) (1996), African Francophone Writing: A Critical Introduction, Oxford: Berg.

Mannoni, O (1964), Prospero and Caliban: The Psychology of Colonization, trans P. Powesland, New York: Praeger.

Memmi, Albert (2003), The Colonizer and the Colonized, trans. H. Greenfeld, London: Earthscan.

Memmi, Albert (1984) Dependence, trans. P. A. Facey, Boston: Beacon.

Memmi, Albert (2000), Racism, trans. S. Martinthorp, Minneapolis: University of Minnesota Press.

Memmi, Albert (1971), The Scorpion, trans. E. Levieux, New York: Grossman.

Memmi, Albert (ed.) (1985), Ecrivains francophones du Maghreb, Paris: Seghers.

Monego, Joan Phyllis (1984), Maghrebian Literature in French, Boston: Twayne .

Moore-Gilbert, Bart (1997), Postcolonial Theory, London: Verso.

Munday, Jeremy (2001), Introducing Translation Studies: Theories and Applications, London: Routledge

Nguyen, Nathalie Huynh Chau (2003), Vietnamese Voices: Gender and Cultural Identity in the Vietnamese Francophone Novel, DeKalb: Southeast Asia Publications, Northern Illinois University.

Niranjana, Tejaswini (1992), Siting Translation: History, Post-structuralism and the Colonial Context, Berkeley: University of California Press.

Robinson, Donald (1997), Translation and Empire: Postcolonial Theories Explained, Manchester: St Jerome. 
Roskies, David (ed.) (1993), Text/Politics in Island Southeast Asia, Monographs in International Studies, Southeast Asia Series no. 91, Athens OH: Ohio University.

Waldrop, Rosmarie (1989), "Silence, the Devil, and Jabès" in The Art of Translation, in (ed._ R. Warren), Boston: Northeastern University Press, pp. 225-236. 